\title{
Accounting for equality: Gender budgeting and moderate feminism
}

\begin{abstract}
This paper sheds light on the relationship between quantification and calculative practices of accounting and moderate feminism. Drawing on a case of gender budgeting in Austria and the literature on social studies of accounting, I show how gender equality initiatives are translated into practice and come to codify the governance of gender relations through calculative practices that further the logic of neoliberal governmentality, rather than fundamentally challenging it. As such, this paper provides an account of one site of the neoliberal recuperation of feminist critique through technologies of quantification and accountability.
\end{abstract}

\section{Keywords:}

Feminism, neoliberalism, gender equality, social studies of accounting, governmentality 


\section{Introduction}

Numbers are one of the dominant modes of information used in organization, decision making and politics. Contemporary forms of organising are unthinkable without quantification and calculative practices, but numbers are not merely technical achievements: quantification carries a form of political rationality (Alonso and Starr 1987, Rose 1991, Hopwood 1992, Porter 1996, Rose 1999, Desrosières and Naish 2002, Porter 2004). Previous research has demonstrated a constitutive relationship between numbers and politics: the exercise of politics depends upon numbers, but the very act of social quantification is politicised and our political imaginary is shaped by statistical representation (Rose 1991). The political efficacy of numbers is paradoxically a result of their promise to "de-politicize" politics by appearing as neutral technologies (Rose 1991).

This paper extends our understanding of moderate feminism by theorising the ambivalent relationship between feminist politics and accounting. In feminism, calculative practices like cost/benefit calculation, performance evaluation, and the quantification of difference, are a matters of political concern. On the one hand quantification is understood to de-politicise feminism, translating political demands into matters for technocratic management (Budgeon 2011). On the other hand, quantification is a powerful way to make feminist concerns visible (Bergmann, Gubitzer et al. 2004, Klatzer 2008). Over the past three decades, gender equality has moved from the margins to the centre of political debate, partly because of the visibility given to it by quantification. Equality is widely acknowledged as a positive social value, and has become institutionalised in a context of evidence-based management, audit mechanisms, new public management and other forms of governance that rely on measurement and counting. It has been operationalised through a range of strategies, like women's quotas and impact indicators. 
Despite the importance of quantification in governance, little attention has been paid to its impact on feminist politics and practices. With a focus on accounting, and related technologies such as auditing, the contribution of this paper is to extend our understanding of the emergence of moderate feminism and describe how a feminist initiative became de-radicalized in the process of institutionalization, to become a more compromising, reformist approach.

This paper provides an account of one such site of the neoliberal recuperation of feminist critique through technologies of quantification and accountability: gender budgeting in Austria drawing upon empirical research conducted between 2009 - 2012 on the problematization and operationalization of gender budgeting in Austria. Gender budgeting initiatives started out as a criticism of budgeting decision-making processes and the ways in which they reinforced gender inequalities. Moving beyond critique, however, gender budgeting has developed into a set of practices linking public sector budgeting with gender equality objectives. Diverse actors, such as accountants and gender experts seek to hybridize gender expertise and accounting techniques in pilot projects to implement equality policies through management accounting.

The paper is structured as follows. The next section reviews the literature on feminism, and social studies of accounting to problematize modes of organising that rely on quantification, accounting and auditing. The following section expands on this by introducing governmentality as a theoretical framework for analysing the emergence of gender budgeting as an element of moderate feminism. In this sense moderate feminism is not a well-defined conceptual starting point but the outcome of historical processes that link specific discourses, technologies and knowledge to constitute political problems and solutions. This framework is followed by an analysis of gender budgeting in Austria, concluding that gender equality has become an element of neoliberal governmentality, working through neoliberal rationalities, rather than in opposition to them. The paper concludes by suggesting that gender budgeting 
enabled the recuperation of more radical feminist political programmes by translating the demand for equality into a set of neoliberal, calculative practices of governmentality.

\section{Governing equality: feminism, numbers and organizing}

\section{Organising feminism}

Feminism is organised in diverse forms and needs to be understood in its plurality. Over time different understandings and concepts of feminism have emerged, for example third wave feminism or postfeminism. However, certain trends in the development of feminism are problematized across those debates. In her analysis of third wave feminism Budgeon (2011) points out that feminism is characterised by diversity, fragmentation and internal contestation, which produces a series of historically unique contradictions Third wave feminism is characterised by a movement of feminist values and practices into mainstream social institutions and popular consciousness, leading to a broad acceptance of gender equality and empowerment in practice as well as in theory. Feminism today has gone beyond protest and is now embedded in different organizational forms, for example in civil society projects shaping political discourse and social goals, or governmental programmes institutionalised as policies in departments and ministries (Walby 2011). Feminism is no longer a protest movement but rather organised within, as well as outside, the state and is therefore increasingly embedded in institutions. Such institutionalised forms of feminism are often not recognised as feminist, because the dominant understanding of feminism is narrowly limited to protest and popular culture. 'Feminism can be less visible but no less significant when it forms coalitions with other social forces and joint projects, which are not explicitly labelled feminist' (Walby 2011: 24). Despite concerns that institutionalisation may lead to feminists 'abandoning their original radical ideas and demands' (Walby 2011: 57), feminism has become increasingly influential 
through stronger coordination via coalitions (Ferree and Hess 1995), alliances (Jakobsen 1998), and networks (Keck and Sikkink 1998).

By mainstreaming feminist aims, gender equality has become widely accepted as a social good and has been institutionalised through quotas, state strategies and equality acts, and has become a symbol of modernity (Budgeon 2011). Some feminists are concerned, however that gender equality is increasingly framed as central to the realisation of both modernisation and economic efficiency (Squires 2007). McRobbie states that third wave feminism has reworked equal rights feminism' to render it 'compatible with liberal democracy' is consistent with the modernisation agenda of neoliberal politics agenda (McRobbie 2009). In other words, gender equality approaches such as gender mainstreaming have made equality a part of governance structures which are organised through the normalisation and institutionalisation of a neoliberal economic agenda. Critics of gender mainstreaming raise concerns that this approach is a top-down technocratic advocacy that translates gender equality into technical processes, reducing feminism to series of procedures, such as impact assessments, that eschew both political participation and normative contestation in their reliance upon professional expertise and evidenced based indicators (McRobbie 2009). This does little to challenge the dominant, neoliberal agenda, so the implementation of gender mainstreaming is effectively limited to a rhetorical change only (Squires 2007).

In order to understand the emergence of moderate feminism I suggest that the relationship between feminism and neoliberalism needs to be unpacked and pluralised. The emergence of neoliberal feminism is analysed for example, by Rottenberg (2014) who understands discourses of 'lean in' as symptomatic of a larger cultural phenomenon in which neoliberal feminism is displacing liberal feminism and as a consequence seems perfectly in line with the evolving neoliberal order where feminist subjects accept full responsibility for their own well-being and self-care based on a cost-benefit calculus. While this literature looked into the individualization 
of equality issues and the responsibilization of women for their own well-being, less attention has been paid to the role of accounting and related technologies in the management of gender equality. Accounting is conventionally understood as a neutral technology that reports on established facts but the turn to social studies of accounting has shown that accounting is a performative technology that constructs the objects it reports. In short, accounting does things: it is an actor that structures the social it purports to merely represent, for example providing a vocabulary to make up subjects and give them certain capacities to act.

This is not to suggest that quantification is 'bad' but rather that it has specific political affordances. For instance, demands for transparency and accountability often originate from democratising ambitions, but these demands and discourses are readily appropriated by neoliberal modes of governance. In this sense quantification and accounting are not bad but dangerous. An examination of the existing literature of social studies of accounting and its potential link to contemporary feminism is therefore timely because it illustrates how initiatives to translate gender equality into practice came to codify the governance of gender relations through calculative practices that furthered the logic of neo-liberal governmentality, rather than fundamentally challenging it.

Gender budgeting provides an ideal case to explore these processes as it explicitly connects gender equality with economic governance. In order to understand how gender budgeting is problematized, imagined, translated into strategies in Austria, operationalised and therewith transformed into something it was not, the next section of the paper introduces social studies of accounting as a field that has extensively studied the limitations of quantification and calculation as modes of political intervention.

\section{Social studies of accounting}


In her analysis of the measurement and management of human rights, gender violence and sex trafficking Merry (2016) points out that "quantification in seductive". The use of numbers to describe social phenomena in countable and commensurable terms promises concrete information that allows easy comparison, facilitation of decision making in absence of more detailed and contextualised knowledge, and conveys "an aura of objective truth and scientific authority despite the extensive interpretative work" that goes into the construction of numbers (loc. 126). Merry (2016) argues that indicators are appealing "because they claim to stand above politics, offering rational, technical knowledge that is disinterested and the product of expertise. [...] They address a desire for unambiguous knowledge, free from political bias" (loc. 175-182). The impact of quantification and accounting in forms of governance need to be understood more comprehensively, and particularly the role of quantification in governing equality in the operationalisation of feminist politics. Management relies increasingly on evidence-based decision making, audit mechanism, and result-based management. These forms of governance require knowledge that is classified, categorised, and arranged into hierarchies. The categorization and differentiation are the questions, not the answers; because it is important to understand "why the categories and the relationships between them are constructed as they are, how they work, and how they change... [These categories] have a constitutive, performative function themselves, contribution to the ongoing accretion of associations these categories collect" (Joseph 2014, p. 96) “[B]eneath the 'truth' of quantified knowledge, indicators are part of a regime of power based on the collection and analysis of data and their representation. Rather than revealing truth indicators create it" (Merry 2016, pos.189, 209) and should not be understood as neutral instruments of representation.

The management of social issues increasingly draw upon accounting and auditing technologies such as cost-benefit analysis, impact audits, performance indicators, and rankings (Deegan 2016). Drawing on research on accounting in its social and institutional context (Hopwood 
1983, Hopwood and Miller 1994, Chapman, Cooper et al. 2009) the emergence of different accounting phenomena, such as Discounted Cash Flow Analysis (Miller and Rose 1990), standard costing (Miller and O'Leary 1987), and gender budgeting, can be understood as the outcome of historical contingent processes. New accounting constellations (Miller 1991) appear because different groups of people, vocabularies and technologies are temporarily linked together in a particular moment of time, rather than resulting from linear, rational improvements or functional adaptation in a changing environment. From this perspective, accounting techniques are understood as technologies of government that make it possible to translate political ideals of government into practice. Miller and Rose (2008), for instance, have studied the ways that accounting numbers and metrics have created knowable and manageable subjects. Accounting numbers produce a specific form of mobile knowledge that enables management to act upon individuals and organisations from a distance. Accounting thus makes modern modes of government possible and judgeable: Possible, because it helps to make up the object upon which government is required to operate (Rose 1991); Judgeable, because the critical scrutiny of authority is increasingly conducted in the language of numbers, by employing rates, trends, graph and numerical comparison. Thus, calculative practices are crucial techniques for modern government.

Because of their centrality to modern government, technologies like accounting are problematized and mobilized by a variety of political programmes to intervene in social life by making 'things' visible and manageable (Mennicken and Miller 2012). through commensuration, accounting enables a colonization and economization of domains previously thought to be 'non-economic' (Miller and O'Leary 1987, Miller and O'Leary 1993, Miller and O'Leary 1994, Miller 2001, Kurunmäki 2004, Kurunmäki and Miller 2006, Miller and Rose 2008, Kurunmäki and Miller 2010, Mennicken and Miller 2012, Cooper 2015). One of these domains is gender equality. The ways in which calculative practices have been mobilised to 
make gender relations visible and manageable, thereby bringing gender into the purview of neoliberal modes of governance and regulation, is both a result of, and one of the main problems with, the gender mainstreaming approach.

\section{Theoretical framework: Governmentality studies}

To understand this further, and to recognise some of the problems arising in this approach this approach, it is useful to have a clearer idea of what government is, and what is distinctive about neoliberal forms of government. Foucault (2009) proposed a definition of the term 'government' as 'the conduct of conduct' which he understands as a form of activity aiming to shape, guide or affect the conduct of some person or persons. In his lectures on governmentality he is particularly concerned with government in the political domain and understands 'the art of government' or 'the rationality of government' as 'a way or system of thinking about the nature of the practices of government (who can govern; what governing is; what or who is governed), capable of making some form of that activity thinkable and practicable both to its practitioners and to those upon whom it was practised" (Burchell, Gordon et al. 1991, p. 3). These calculated and rationalised activities are understood to be undertaken by a multiplicity of agencies employing a variety of techniques and forms of knowledge to shape conduct by working through desires, aspirations and beliefs, for definite but shifting ends, with a diverse set of relatively unpredictable effects (Dean 2009). Practices that contest and call into question the 'art of government' are referred to as 'problematizations': ways of interrogating past, present and potential alternatives that often include modes of evaluation of success and failure (Dean 2009).

As groups of calculative practices stabilize, becoming a systematised way of 'doing things' we can refer to 'regimes of practices (Dean 2009). Regimes of practices are concerned with ways of directing the conduct of the self and others which can be analysed along four axes: 
(1) Visibilities. The first dimension is concerned with forms of (in) visibilities. Here budgets are understood as objects with shadow and light, ways of visualising fields to be governed which create at the same time fields of invisibilities.

(2) Technologies. The second dimension concerns the technical aspect of government that translate visibilities into practices. These technical means are a condition of government and often impose limits over what is possible to do, e. g. the government of national economies rely on very specific economic models and instruments, national budgets have a specific form and rely on certain procedures in the budgeting process.

(3) Rationalities. The third dimension concerns the form of knowledge that arises and informs governing: What form of knowledge, expertise and means of calculation are employed in practices of government? How do these give rise to specific forms of truth? How does 'thought' seek to transform practices?

(4) Identities. The final dimension is concerned with the forms of individual and collective identity through which governing operates. What statuses, capacities and attributes are assumed of those who exercise authority (bureaucrats and professionals) and those who are to be governed (women, men, employees)? What duties and rights do they have? How are they problematized and to be reformed?

From a governmentality perspective gender budgeting can be understood as (i) a regime of practices which aim at problematizing accounting knowledge and practices, as well as (ii) a regime of practices managing gender equality. However, this is not an unproblematic endeavour because as Miller and Rose (1990) point out "the will to govern" is not about an analysis of a successful or less successful implementation or operationalization of a political programme but rather an analysis of messy and variable operationalization of political programmes. In the case of gender budgeting initiatives we can't assume that "gender" or 
"equality" are given and uncontested categories. Empirical research is needed to understand struggles over meaning in efforts to make gender relations and gender (in-) equality visible and governable.

After a description of my methods I will examine how budgets became a 'feminist concern' in Austria: how the way of doing budgeting, the language of quantification, and forms of knowledge and expertise were problematized from different feminist perspectives, and how performance indicators became the solution to the problem of gender inequality despite the earlier feminist critiques of quantification and management accounting techniques. Finally I will conclude with a discussion of the relationship between moderate feminism and quantification.

\section{Research design}

In 2009 gender budgeting became part of the Austrian Constitution and by the end of 2012 pilot projects in public institutions had implemented gender budgeting in the course of the budgetary law reform. In order to understand what gender budgeting is and how it emerged I draw upon critical discourse analysis (Jäger 2004), following Foucault (2012), understanding of discourse as "flow of knowledge through time". Discourses become powerful forms of historical accepted knowledge producing 'truth' and informing individual and collective action (Jäger 2004).

In this analysis one text appears as a central text in Austria: BEIGEWUM (2002), 'Frauen macht Budgets!'. Definitions, concepts and strategies were picked up from this source and ideas from the book travelled into many gender budgeting initiatives in Austria. Jäger (2004) calls these types of central and influential texts with a political agenda 'programmatic texts'. In the analysis section of this paper I will draw heavily on examples and quotes from this source because it was the first comprehensive feminist political programme on gender 
budgeting in Austria. Methodologically it is important to draw attention to this text because it shows which elements from the 'programmatic ideal' are later linked to organizational practices and related discourses and which elements 'get lost in translation' and which ones are 'reprogrammed'. To investigate the operationalisation of gender budgeting data was collected from different texts, such as comments on the budgetary law reform, minutes of parliament, practical guidelines and training material on the implementation of gender budgeting in different gender budgeting initiatives, online material produced by the Ministry of Finance to support the implementation of gender budgeting, guidelines and data produced by three Austrian universities, the university's performance contracts with the ministry of education, their mission statements and strategic plans. In addition to the document analysis I conducted 16 semi-structured interviews of 30-180 minutes with gender budgeting experts, women who published on gender budgeting, gender equality staff, gender 'consultants', quality administrators and managers, and management accountants in universities, staff in the ministries of finance, education, science and research.

Table 1: List of interviewees

\begin{tabular}{|c|c|}
\hline Interviewee 1 & Gender budgeting expert \\
\hline Interviewee 2 & Gender budgeting expert \\
\hline Interviewee 3 & $\begin{array}{l}\text { Gender budgeting expert, gender consultant (public } \\
\text { institution) }\end{array}$ \\
\hline Interviewee 4 & Gender budgeting expert, Council of Europe \\
\hline Interviewee 5 & $\begin{array}{l}\text { Human resources (HR) manager, university, } \\
\text { responsible for gender budgeting implementation }\end{array}$ \\
\hline Interviewee 6 & $\begin{array}{l}\text { Gender budgeting expert, HR / Quality Management } \\
\text { staff (university), responsible for gender budgeting } \\
\text { implementation }\end{array}$ \\
\hline Interviewee 7 & Gender equality committee member (university) \\
\hline Interviewee 8 & $\begin{array}{l}\text { Gender statistics expert, Statistician for university } \\
\text { statistics and evidence based management of } \\
\text { universities, Ministry of Science and Research }\end{array}$ \\
\hline Interviewee 9 & $\begin{array}{l}\text { New public management expert and budgetary law } \\
\text { reform (including gender budgeting) expert, head of } \\
\text { finance, Ministry of Finance }\end{array}$ \\
\hline Interviewee 10 & Management accountant, university \\
\hline Interviewee 11 & $\begin{array}{l}\text { Quality manager (university performance contracts } \\
\text { and gender budgeting), university }\end{array}$ \\
\hline Interviewee 12 & Quality manager, university \\
\hline Interviewee 13 & $\begin{array}{l}\text { Gender equality working group member, Ministry of } \\
\text { Finance }\end{array}$ \\
\hline
\end{tabular}




\begin{tabular}{|l|l|}
\hline Interviewee 14 & Gender budgeting expert, Ministry of Finance \\
\hline Interviewee 15 & Gender budgeting expert, gender consulting \\
\hline Interviewee 16 & $\begin{array}{l}\text { Consultant for outcome controlling of politics, Office } \\
\text { of the Federal Chancellor }\end{array}$ \\
\hline
\end{tabular}

\section{Accounting for equality - the emergence of gender budgeting in Austria}

(i) Problematization of national budgets: Feminist critique of the state, the budget and the accounting profession

"[T]he history of government might well be written as a history of problematizations, in which politicians, intellectuals, philosophers, medics, military strategists, feminists and philanthropists have measured the real against the ideal and found it wanting" (Miller and Rose 2008, p. 61)

In order to understand the emergence of gender budgeting in Austria the analysis starts with an investigation of practices which contest and call into question the 'art of government'. These practices are referred to as 'problematizations': ways of interrogating past, present and potential alternatives (Dean 2009).

Among feminist academics and activists it is widely acknowledged that women are disproportionally affected by austerity measures and financial crises (Walby 2009, Karamessini and Rubery 2013). In Austria, an increasing tax and contribution ratio, cuts in social spending, including women's projects (Buchinger, Gubitzer et al. 2009), and the election of a right-wing National-Liberal Government (FPÖ/ÖVP), prompted a critique of the economic and social policies of the late 1990s (BEIGEWUM 2002: 178). Alongside the publication of the United Nations Development Fund for Women (UNIFEM)'s "Progress of the World's Women 2000" Report, this was the context in which the first discussions, and feminist studies, of budgets' gender impacts appeared (Mayrhuber 2006). A non-Governmental committee BEIGEWUM (committee for alternatives in social, economic and environmental policy) 
founded a working group to introduce gender budgeting to Austria. In 2002, BEIGEWUM published the first comprehensive book on "engendering budgets" called "Frauen macht Budgets". The translation of the title is twofold. On the one hand it was a call for women to get involved in budgetary policy: an activation of women. On the other hand, the word "macht" (make) could be understood as the noun "Macht" (power) which translates into "Women, Power, Budgets!" and hints at the analysis of gender power relations of budgets and budgetary policy.

One of the main themes in the gender budgeting discourse is the welfare state because women's policies and gender equality policy are strongly connected with the Austrian welfare state model. The feminist debate about the welfare state in Austria is characterised by two 'ideal' positions: On the one hand, the state is understood as a patriarchal and misogynistic system of power that reproduces dependencies of women.

'Feminist theories of the state demonstrate in diverse ways the intrinsic linkage of the state and masculinity. They understand the state as a by men and for men constructed institution $[\ldots]$ and the governmental budget as a patriarchal instrument of power which reflects the historical political-economic structures of society and its power relations' (BEIGEWUM 2002: 58).

One the other hand, the welfare state is not so much understood as a system of domination but rather as 'springboard to autonomy' (Gerhard, Schwarzer et al. 1988). The concept 'state feminism' best describes the political alliance between feminism and the welfare state against 'neoliberal tendencies' and the 'economization of the social'. The assumption is that a critical mass of 'femocrats' (feminist bureaucrats) within the bureaucratic system of the welfare state can achieve a transformation of the welfare state towards 'gender democracy' and women's policies (Sauer 2001). Feminist theories of the state describe the link of the state and 
masculinity by focussing on the historical constitution of the modern state, its structures and interests. Angelo et al. (2002) argue that with the analysis of the genesis of the modern state the inherent masculinity of the budget becomes apparent. The state is described as 'product of war' with essential relevance of the military which is seen not only as 'archetype of bureaucracy' but also as construction of 'masculinity inherent in the state' (BEIGEWUM 2002: 54). The national budget is framed as 'crystallisation of state action' (BEIGEWUM 2002: 57) and all activities of the state which are related to monetary transactions are thus reflected in the national budget. The problematization of the 'gendered nature of the budget' is informed by gender theory and emphasises that budgets are 'patriarchal instruments of power which can be neutralised' (BEIGEWUM 2002: 58, my emphasis). Critical feminist perspectives of the state and the national budget view power as a structural component of society and social relations where social hierarchies are products of modes of production, historical social structures, and ideology. In the gender budgeting discourse power tends to be conceptualised as negative: it dominates, limits, exploits, and controls.

\section{Budgeting as technocratic exercise of domination and exclusion}

In the gender budgeting discourse budgets are understood as powerful political technologies through which political priorities are translated into numbers and vested with resources. In response to austerity policies and the crisis of the welfare state the problematization of accounting technologies and quantification became a major topic in the discourse.

The national budget is framed as 'a set of figures disguising facts' (BEIGEWUM 2002 :12) and its 'professed neutrality' as economic instrument is questioned. The technical complexity of budgets is said to 'require expert knowledge' and 'exclude others which leads to a bureaucratic, and undemocratic budgeting process which is dominated by men'. 
'Numbers which describe the situation of the state, municipalities, districts or organizations are too often presented as a result of practical constraints, as irrevocable. These numbers are, however, results of societal and gender power relations, but these power relations are mystified by the pretended objectivity and neutrality of numbers' (Bergmann, Gubitzer et al. 2004).

Further, budgeting processes are problematized as practices of exclusion. This argument is based on a critique of the accounting profession and expert knowledge, which is said to 'lead to the exclusion of laypeople and an undemocratic budgetary process' (BEIGEWUM 2002).

'Economic policy, in particular budgetary policy is key element of state action. However, in many cases economic-political decisions are deprived of any democratic discussion as they are represented as technical exercise of "experts" (original accentuation). Therewith, important interrelations and social implications are disguised' (BEIGEWUM 2002: 9).

The legitimacy of budgets are called into question by criticizing the 'professed objectivity of numbers', which disguise power relations because budgets are presented as 'gender-neutral'. This critique implies that if gender is added as a category of analysis and becomes 'visible', then 'Governmental budgets can be neutralized as technology of power' (BEIGEWUM 2002: 58). This cannot be done exclusively through numbers, however, as if political objectives are articulated in terms of numbers and ratios, but not in terms of content, this disguises changes of policy (BEIGEWUM 2002: 85). If quantification cannot meet the concerns of qualitative objectives (BEIGEWUM 2002: 165), then budgets need to combine quantitative and qualitative aspects.

The feminist critique of quantification in economics is based on an understanding of the state as an intrinsically gendered social construct. The findings contain three prominent intrinsically 
linked issues which are backed-up by feminist knowledge from research in the field of feminist economics and gender studies: (1) the problematization of budgets as technology of domination because budgets are seen to reflect the masculine politico-economic power relations in society; (2) the problematization of budgeting as technocratic exercise which is said to mystify these power relations by appearing to be a neutral instrument; and (3) the problematization of budgeting as a technology of exclusion which is based on the critique of the accounting profession and expert knowledge which leads to the exclusion of laypeople in the budgetary process.

Programmatic Ideals: How to overcome the ills of the state and the budget?

In response to the problematization of the state and budgets, certain strategies and tactics are articulated in form of 'programmatic ideals' or 'programmes' to overcome the resultant ills. Programmes are not simply formulations of wishes or intentions. Rather, they lay claim to a certain knowledge of the problem to be addressed, for instance knowledge of the economy and the status of women in society are essential elements in programmes that seek to exercise legitimate and calculated power over questions of gender equality. In this sense, governing equality requires that it can be represented, "depicted in a way which both grasps its truth and re-presents it in a form in which it can enter the sphere of conscious political calculation" (Miller and Rose 2008, p. 62). Theories of social science, thus provide a kind of "intellectual machinery" (Miller and Rose 2008) for government, "in the form of procedures for rendering the world thinkable, taming its intractable reality by subjecting it to the disciplined analyses of thought" (Miller and Rose 2008, p. 62). To put it differently, the common axiom of programmes is that an object needs to become 'knowable' in order to become manageable. That means the government of gender equality draws upon contested concepts of 'gender' and 'equality' and simultaneously produces knowledge and 'truth' about gender and equality. Programmes are rationalised or reasoned in a certain way and draw upon particular knowledges 
and technologies for representing, and intervening in the production of the object. As such they necessarily have a political rationality.

The predominant terms in the gender budgeting discourse are 'equality', 'transparency', 'democracy', 'participation', 'empowerment' and 'accountability'. Equality is linked, on the one hand, to a redistribution of resources of money, power and time. Questions are asked like how women and men are effected by budgetary allocation as users of public services, who the victims of austerity politics are, and how an equal distribution of resources might look when it takes 'the needs of women' into consideration? These questions are mobilised mostly on the left, in academia, and party politics by the Green Party and the Social Democratic Party. In contrast, conservative and right-wing political parties mobilise the notion of equality as recognition of the contribution of women's work and emphasise that 'women deserve the choice to stay at home'. These two strategies were increasingly presented in the political media discourse as alternatives between redistribution and recognition (Fraser and Honneth 2003) which are framed to exclude each other.

To transform budgets from a 'technology of domination' into a 'technology of democracy' a need for more transparency is articulated in the discourse. Transparency is linked to three things: First, to the (in)visibility of gender power relations in the budget. Here the main effort is to make gender relations visible by means of gender disaggregated statistics and gender impact assessments. Second, a call for more transparency is related to the disclosure of political interests which are said to be hidden behind numbers and technical complexity. Finally, transparency is needed in the budgeting process because it takes place behind closed doors and therefore is exclusionary.

Gender budgeting as political programme aims at a transformation of national budgets as technologies of power. Programmatic ideals and aspirations aim at (1) increasing the 
transparency of political priorities in income and expenditure (BEIGEWUM 2002: 86, 112, 180), (2) representing the budget's impact on women, children and men, especially the impact on unpaid work and the care economy (BEIGEWUM 2002:10, 16, 17, 189), (3) transforming the bureaucratic, hierarchical and male-dominated budgeting process towards transparency and participation (BEIGEWUM 2002: 18, 19), (4) ensuring the application of gender expertise in the budgeting process (BEIGEWUM 2002: 18, 19), and (5) monitoring the Government's accountability and commitment to gender equality.

In line with governmentality studies I understand government as a domain of strategies, techniques and procedures through which different forces seek to render programmes operable. These heterogeneous mechanisms and practices are defined as technologies of government through which political rationalities and programmatic ideals are articulated and become deployable (Miller and Rose 2008). Technologies in this sense should not be understood as matters of implementation but rather as assemblage of diverse forces. In the discourse of gender budgeting different technologies are suggested in order to overcome the ills of budgetary policy and to translate the ideals of gender budgeting into practice:

First, technologies are proposed which should improve the capacity for participation, such as raising awareness through gender and wealth statistics, gender impact assessments, techniques to increase women's self-esteem so they feel able to become involved in economic policy (BEIGEWUM 2002: 190), teaching and activation of women and men in civil society, inter-organizational cooperation between NGOs and government departments, a women's quota for political and administrative positions, and the extension of feminist networks.

Second, specific technologies are recommended to support the application of gender expertise in order to transform budgeting processes and the accounting profession, for example seminars for the exchange of expertise and operational knowledge on gender budgeting, 
specifically targeted at civil servants working in the field of budgeting and staff employed in gender equality units. Gender budget departments within Ministries should be created. In these departments, gender experts and finance experts should be responsible for the implementation of gender budgeting. The activities of an inter-ministerial working group for gender mainstreaming should be strengthened by creating a steering committee for gender issues in collaboration with NGOs and with support of a scientific committee. A "gender budget forum" made up of representatives of feminist organizations and NGOs, politicians, researchers and national and regional representatives of finance and gender departments should be established to monitor the process of implementation and to provide expertise and consulting.

Third, there is a call for technologies to increase accountability, transparency and democratic control: the development of methods for a 'gender analysis of the budget', the development of performance indicators to increase accountability, the development of genderresponsive incentive systems in macroeconomic policy, periodical reports, and the creation of a "Watch Group" to monitor the process and maintain external pressure on the Government.

Gender budgeting as a programmatic ideal is presented as a strategy of emancipation and democratisation, responding to austerity measures and the gender-unfair allocation of budgetary resources. The main interest of gender budgeting at this point is an analysis that focuses on the social and economic impacts of budgets on women's situation in life and the reproduction of gender roles in society through budgeting, but an alternative set of technologies is needed in order to operationalise gender budgeting. In the tradition of social movements, these suggestions focus on technologies of voice and representation (Yeatman 1994) to enhance participation, discussion, and the scope of action but the focus on gender impacts also creates the desire to quantify and to measure these impacts, and to produce gender disaggregated data that make gender inequality visible. It is in this context that the first technologies of quantification and calculation are proposed as a means of making inequality 
more visible. At this point they are not, however, suggested as means to actually realise gender equality. The desire for transparency and accountability are still a radical demand and have not yet become part of the bandwagon of neoliberalism (McKinlay and Pezet 2017, p. 203).

(ii) New public management outcome orientation: Gender budgeting and equality performance

The work on gender budgeting at a federal level in Austria started in 2004. Gender budgeting was recommended as a way 'to analyse budgetary activities with regard to its impact on women and men' (Government Resolution 2004). Under pressure from the Social-Democratic Party and the Green Party, as well as non-Governmental organisations, gender budgeting was included in the resolution for a Budgetary Law reform in 2007 (Appelt 2009).

In the course of reforming the Austrian Budgetary Law gender budgeting was linked to performance-based management (Leistungsorientierte Steuerung). The reform focused on a 'modernisation of public budgeting', 'driven by an international trend towards New Public Management' (NPM) and aimed to respond to demands for 'transparency', 'efficiency', 'flexibility', 'impact orientation', and 'budget discipline' (Steger 2010, Steger 2012). These aims were operationalised through different concepts such as impact assessments (ex ante), impact-oriented management (as a rolling process), and evaluations through performance indicators (ex post) (Seiwald, Geppl et al. 2011). Socio-political objectives were translated into impactful public services that could be made visible and manageable through quantification and performance indicators to 'optimise efficiency and effectiveness' (BMF 2012).

The most prominent socio-political objective in this reform was gender equality. In the course of reforming the Austrian Budgetary Law gender budgeting became part of the Austrian Constitution (effective from 2009). One interviewee explained the prominent role of gender budgeting in the reform as follows: 
'Some people mainly wanted to implement budget discipline, others wanted for example gender budgeting. The achievement was -in the end- that everybody agreed on a package which included issues that were important to them but at the same time accepted other issues of the package. [...] That is how it was possible to decide unanimously on gender budgeting' (Interviewee 9).

At this point gender equality was linked to a performance-based budgeting initiative where gender equality became an 'impact objective' that needed to be included in all strategies, mission statements, and performance contracts between the Government and all public institutions. Gender equality was, however, not defined in the legislation. Public sector institutions were left to articulate where gender inequalities appeared in their organisation, how they could make these inequalities visible, and how they intended to manage gender (in)equality. This generated difficult questions of how to understand gender equality and its relation to budgets: Who are the beneficiaries of resources? How is the population divided and categorised to understand gender power relations? What are the effects of resource (re)allocation? To what extent does budgetary resource allocation change or reproduce gender power relations, and how do we know?

According to guidance from the Austrian Ministry of Finance on gender budgeting and performance-based budgeting, the reform was intended to make gender equality an outcome objective connected to numbers: 'The outcome orientation has to be endorsed - also particularly with regard to the objective of the equality of women and men - as an integral part of budgeting [...]' (Budgetary Law effective from 2013). In the explanation report on the law it stated: '[...] the principle of outcome orientation, particularly with regard to the equality of women and men, has to be implemented [...] by the representation of outcome objectives, measures and indicators' (BMF, Parliamentary Material 480dB_XXIV.GP-RV: 27). 
This New Public Management reform was framed by some feminist academics and practitioners as an opportunity for gender equality, for example Klatzer (2008: 14) pointed out: 'it open [sic] new opportunities and instruments to improve the gender equality performance of budgeting and policy making'. Performance measurement was seen to produce 'powerful facts' that could not be easily ignored. Indicators and quotas were seen as disciplinary mechanisms, if they are 'implemented correctly', requiring individuals to comply in order to lock-in values of equality.

Management accounting techniques were thus constructed as mean of achieving gender equality, though not without some reservation. Feminists still criticized the exclusion of unpaid work in the performance-based budgeting approach, claiming that 'the almost exclusive reliance on quantitatively measurable performance indicators' (Klatzer 2008), and the 'the inherent ideological bias in concepts of performance orientation' favoured 'a restructuring of the public sector according to business standards and... a reduction of the public sector as such' (Gubitzer, Klatzer et al. 2008). This challenge to the idea that equality should become a performance indicator was undermined, however, because gender budgeting came to be seen through the dominant understanding paradigm of performance-based budgeting:

'[...] there seems to be a direct and logical link between PBB [performance-based budgeting] and gender budgeting as both focus on results and a broader cycle of policy planning, implementation and evaluation. Enhanced accountability is an issue for both approaches. Equally, better governance structures, transparency, enhanced participation and democracy are elements in both' (Klatzer 2008: 1).

In linking gender equality and performance management, a managerial rationale was tacitly adopted. The importance of measuring performance became uncontested. By discursively connecting equality objectives with the 'correct' indicator - gender - performance-based 
budgeting offered a solution for gender equality policy, rather than a point of contestation and object of critique:

'The choice of indicators is crucial because it determines the quality of PBB [performance-based budgeting] as a steering instrument. A lot has been written about the selection of the right number and quality of indicators in order to effectively capture the results of budgetary policies and of delivery of government services and goods. [...] Integrating the gender dimension refers not only to engendering an existing set of indicators, but also the construction of specific gender indicators' (Klatzer 2008, p.10).

In the course of New Public Management reforms, issues like gender equality were framed in terms of measures and indicators. Objectives were formulated in terms of indicators that could be used to compared institutions or changes over time. The methods of calculation and the quantitative databases should be standardised so that social impacts would be statistically visible, comparable and optimised. This could lead, as Otto and Ziegler (2006) argued, to a spread of evidence-based measures and programmes with an underlying assumption to optimise political objectives through 'mechanical and "objective" procedures' which might lead to a reification of political objectives (Brandtner, Kinschner et al. 2013).

\section{Conclusion: Politics of quantification and implications for the emergence of moderate}

\section{feminism}

Feminism, as Walby (2011) argued, is not a social movement of outsiders engaged in protest against holders of institutional power but is increasingly practiced through 'engagement with power'. Feminist projects like gender budgeting produce dilemmas for feminist scholarship and action. Are they examples of the recuperation of a radical feminist critique into a neoliberal orthodoxy of performance measurement and competition, or that they subversive 
colonisations of dominant logics, hybridising and transforming the mainstream. Gender budgeting in the context of Austrian budgetary law reform appears to be an example of the former: a case where feminist ideals are co-opted by a neoliberal policy reform. When national budgets became a feminist concern in Austria, budgets were framed as technologies of domination and exclusion that need to be transformed to become more inclusive, democratic and emancipatory. One prominent issue of problematization was a critique of the apparent neutrality and objectivity of numbers. It is thus surprising that with the operationalisation of gender, statistics and performance indicators became the preferred technologies to manage gender equality.

Gender equality and how it is framed in Austrian budgetary law reform, can be understood as neoliberal governmentality because it is presented as a strategy of need formation (Yeatman 1994) where women are framed as clients or customers of the state. A fair distribution of resources appears to be informed by 'user needs' and evidenced through the quantification of those needs by means of accounting and audit technologies such as gender impact assessment. Calculative practices enabled a neoliberal government of gender equality because gender equality performance is based on ideas of efficiency, optimisation and competition. Gender equality is framed as modern, and incentive systems are put in place to integrate women into employment. Gender equality issues are increasingly tackled with calculative, managerial technologies that are transplanted from the private sector, such as SMART indicators, benchmarks and audits. A gender-as-a-variable approach focuses on the collection of sexaggregated data and gender statistics, and the development of gender indicators are increasingly of interest to feminist academics and practitioners. Studies in accounting (Rose 1991; Miller and Rose 2008) point out that quantification

'can help democratize spheres previously dominated by certain professional or technocratic elites, but the apparent de-politicization that this brings can simply shift 
the terrain of politics, or transfer control to other professional groups. Numbers and calculations are never simply technical solutions to allocation and accountability problems, never unproblematic vehicles of transparency'(Mennicken, Miller et al. 2008: 5).

Every mode of calculation produces a particular form of visibility that produce specific possibilities for intervention. I suggest that feminist scholars pay closer attention to practices of quantification and calculation to reflect on their (intended and unintended) effects for feminist action. Impacts of quantification, metrics and algorithms on individuals and population become increasingly important at present. Social studies of accounting suggest that we need to pay attention to calculative practices and follow how technological infrastructures and social relations constitute and re-constitute each other.

\section{References}

Alonso, W. and P. Starr (1987). The politics of numbers, Russell Sage Foundation Publications. Appelt, E. (2009). Gleichstellungspolitik in Österreich: eine kritische Bilanz, StudienVerlag. BEIGEWUM (2002). Frauen macht Budgets: Staatsfinanzen aus Geschlechterperspektive, Mandelbaum.

Bergmann, N., L. Gubitzer, E. Klatzer, Klawatsch-Treitl and M. Neumayr (2004). Gender Budgeting. Handbuch zur Umsetzung geschlechtergerechter Budgetgestaltung. Wien, Attac Österreich. Brandtner, C., M. Kinschner and T. Polzer (2013). "Unternehmen Österreich? Wirkungsorientierung am Grat zwischen Technokratie und Demokratie." Momentum Quarterly-Zeitschrift für sozialen Fortschritt 2(4): 208-230.

Buchinger, B., L. Gubitzer, E. Klatzer, K. Mitterer, K. Muhr, S. Pirklbauer, N. Schaffer, C. Schlager and M. Schratzenstaller (2009). Gender Budgeting Österreich - Möglichkeiten und Grenzen einer politischen Gleichstellungsstrategie. Gleichstellungspolitik in Österreich. Eine kritische Bilanz. E. Appelt. Innsbruck, Studienverlag: 79-98.

Budgeon, S. (2011). Third wave feminism and the politics of gender in late modernity, Palgrave Macmillan.

Burchell, G., C. Gordon and P. Miller (1991). The Foucault effect: studies in governmentality University of Chicago Press. 
Chapman, C. S., D. J. Cooper and P. Miller (2009). Accounting, organizations, and institutions: essays in honour of Anthony Hopwood, Oxford University Press.

Cooper, C. (2015). "Entrepreneurs of the self: The development of management control since 1976." Accounting, Organizations and Society 47: 14-24.

Dean, M. (2009). Governmentality: power and rule in modern society, SAGE.

Deegan, C. (2016). "Twenty five years of social and environmental accounting research within Critical Perspectives of Accounting: Hits, misses and ways forward." Critical Perspectives on Accounting.

Desrosières, A. and C. Naish (2002). The politics of large numbers: a history of statistical reasoning, Harvard University Press.

Ferree, M. M. and B. B. Hess (1995). Controversy and coalition: The feminist movement across three decades of change.

Foucault, M. (2009). Security, Territory, Population: Lectures at the Collège de France 1977--1978, Macmillan.

Foucault, M. (2012). The archaeology of knowledge, Vintage.

Fraser, N. and A. Honneth (2003). Redistribution or recognition?: a political-philosophical exchange, Verso.

Gerhard, U., A. Schwarzer and V. Slupik (1988). Auf Kosten der Frauen: Frauenrechte im Sozialstaat, Beltz.

Gubitzer, L., E. Klatzer, K. Mader, M. Mayrhofer, K. Muhr, A. Obermair, B. Sauer and C. Schlager (2008). "Gender Budgeting als Beitrag zur Demokratisierung europäischer Wirtschaftspolitik?Endbericht."

Hopwood, A. G. (1983). "On trying to study accounting in the contexts in which it operates." Accounting, Organizations and Society 8(2-3): 287-305.

Hopwood, A. G. (1992). "Accounting calculation and the shifting sphere of the economic." European Accounting Review 1(1): 125-143.

Hopwood, A. G. and P. Miller (1994). Accounting as social and institutional practice, Cambridge University Press.

Jäger, M. (2004). Diskursanalyse: Ein Verfahren zur kritischen Rekonstruktion von

Machtbeziehungen. Handbuch Frauen- und Geschlechterforschung. R. Becker and B. Kortendiek.

Wiesbaden, VS Verlag für Sozialwissenschaften.

Jakobsen, J. R. (1998). Working alliances and the politics of difference: Diversity and feminist ethics. Bloomington, Indiana University Press.

Joseph, M. (2014). Debt to society: Accounting for life under capitalism, University of Minnesota Press Minneapolis.

Karamessini, M. and J. Rubery (2013). Women and austerity: the economic crisis and the future for gender equality, Routledge. 
Keck, M. and K. Sikkink (1998). Activists beyond borders: Transnational activist networks in international politics. Itaca, NY, Cornell University Press.

Klatzer, E. (2008). The integration of Gender Budgeting in Performance-Based Budgeting.

Klatzer, E. (2008). "The interlinkage between Performance Based Budgeting and Gender Budgeting.": 1,2 .

Kurunmäki, L. (2004). "A hybrid profession--the acquisition of management accounting expertise by medical professionals." Accounting, Organizations and Society 29(3-4): 327-347.

Kurunmäki, L. and P. Miller (2006). "Modernising government: the calculating self, hybridisation and performance measurement." Financial accountability \& management 22(1): 87-106.

Kurunmäki, L. and P. Miller (2010). "Regulatory hybrids: Partnerships, budgeting and modernising government." Management Accounting Research In Press, Corrected Proof.

Mayrhuber, C. (2006). Kurzüberblick über Gender Budgeting Initiativen und Projekte in Österreich.

Gneder Budgeting in Europa. Konferenzdokumentation. E. a. N. KLatzer. Wien, Kammer für Arbeiter und Angestellte für Wien: 23-36.

McKinlay, A. and E. Pezet (2017). Foucault and managerial governmentality: Rethinking the management of populations, organizations and individuals, Taylor \& Francis.

McRobbie, A. (2009). The aftermath of feminism: Gender, culture and social change, Sage.

Mennicken, A. and P. Miller (2012). "Accounting, Territorialization and Power." Foucault Studies: 424.

Mennicken, A., P. Miller and R. Samiolo (2008). "Accounting for economic sociology." Economic Sociology 10(1): 3-6.

Merry, S. E. (2016). The seductions of quantification: Measuring human rights, gender violence, and sex trafficking, University of Chicago Press.

Miller, P. (1991). "Accounting innovation beyond the enterprise: Problematizing investment decisions and programming economic growth in the U.K. in the 1960s." Accounting, Organizations and Society 16(8): 733-762.

Miller, P. (2001). "Governing by numbers: Why calculative practices matter." The Blackwell cultural economy reader: $179-189$.

Miller, P. and T. O'Leary (1987). "Accounting and the construction of the governable person." Accounting, Organizations and Society 12(3): 235-265.

Miller, P. and T. O'Leary (1993). "Accounting expertise and the politics of the product: Economic citizenship and modes of corporate governance." Accounting, Organizations and Society 18(2-3): 187-206.

Miller, P. and T. O'Leary (1994). "Accounting, "economic citizenship" and the spatial reordering of manufacture." Accounting, Organizations and Society 19(1): 15-43.

Miller, P. and N. Rose (1990). "Governing economic life." Economy and society 19(1): 1-31. 
Miller, P. and N. S. Rose (2008). Governing the present: administering economic, social and personal life, Polity.

Otto, H.-U. and H. Ziegler (2006). Managerielle Wirkungsorientierung und der demokratische Nutzwert professioneller Sozialer Arbeit, Springer.

Porter, T. M. (1996). Trust in numbers: the pursuit of objectivity in science and public life, Princeton University Press.

Porter, T. M. (2004). "The Culture of Quantification and the History of Public Reason." Journal of the History of Economic Thought 26(02): 165-177.

Rose, N. (1991). "Governing by numbers: Figuring out democracy." Accounting, Organizations and Society 16(7): 673-692.

Rose, N. S. (1999). Powers of freedom: reframing political thought, Cambridge University Press. Rottenberg, C. (2014). "The rise of neoliberal feminism." Cultural Studies 28(3): 418-437.

Sauer, B. (2001). Die Asche des Souveräns: Staat und Demokratie in der Geschlechterdebatte, Campus Verlag.

Seiwald, J., M. Geppl and A. Thaller (2011). Handbuch Wirkungsorientierte Steuerung. Unser Handeln erzeugt Wirkung. B. Österreich. Wien, Bundesministerin für Frauen und Öffentlichen Dienst im Bundeskanzleramt Österreich

Minoritenplatz 3, 1014 Wien

Squires, J. (2007). The new politics of gender equality, Palgrave Macmillan.

Steger, G. (2010). "Austria's budget reform: How to create consensus for a decisive change of fiscal rules." OECD Journal on Budgeting 10(1): 7.

Steger, G. (2012). "Budget reform in Austria: From traditional to modern budgeting." Presupuesto y Gaslo Püblico 69: 147-162.

Walby, S. (2009). "Gender and the financial crisis." Paper for UNESCO Project on Gender and the Financial Crisis, Lancaster University.

Walby, S. (2011). The future of feminism, Polity.

Yeatman, A. (1994). Postmodern revisionings of the political, Psychology Press. 